\title{
Proposed Indicators of Prevention Through Design in Construction Projects
}

\author{
Propuesta de Indicadores de Prevención a Través del Diseño en los Proyectos de Construcción
}

Antonio López-Arquillos (Main and Contact Author) Industrial Engineering. School of Industrial Engineering. Universidad de Málaga. C/Dr. Ortiz Ramos, s/n. 29071 Málaga (SPAIN) investigacioncatedra@gmail.com

\begin{abstract}
The construction industry has a high accident rate worldwide. Because of these negative figures, there are numerous studies by prestigious authors about how to measure the levels of safety and health in construction through indicators. These indicators can be classified based on the following categories: a) Accidents recorded b) Risk assessment, c) Workload, d) Health and safety training, e) Perception of safety and health and f) Health and safety management. However, despite the importance of indicators as a preventive tool, no studies have been found regarding the most appropriate indicators to measure the degree of implementation of the concept of Prevention through Design in civil engineering construction projects. The purpose of this paper is to analyze the main existing indicators to quantify the levels of safety and health in construction, and based on this analysis to propose and validate indicators to measure the Prevention through Design in civil engineering projects, using the staticized groups methodology. The information provided by the new proposed indicators is useful for improving safety levels in construction companies.
\end{abstract}

Keywords: Occupational Health and Safety, Indicator, Prevention through Design, Accident, Construction.

Introduction.

\section{Description of the problem}

The construction industry has one of the highest accident rates worldwide, as reflected in statistics provided by organizations such as the International Labour Organization (ILO), Eurostat, and the Bureau of Labour and Statistics (BLS).

Safety levels in construction are usually measured by different occupational health and safety indicators. UNE 66175:2003 defines indicators as follows: "Datos o conjunto de datos que ayudan a medir objetivamente la evolución de un proceso o de una actividad" (Figures or a set of figures that help one to measure changes in a process or activity objectively) [translation by the author] (AENOR, 2003). These indicators, as the International Labour Organization points out (International Labour

Organization, 2013), are a very useful tool when evaluating the extent to which employees are protected from the dangers and hazards associated with their work. Indicators can be used by governments, building companies and mutual accident insurers to improve health and safety conditions and to develop programmes for better accident prevention. They have a big importance in a correct implementation and performance of a management system based on OHSAS 18001 standard. (British Standard Institution, 2007).

Among indicators of this kind are those for results, which include indicators for incidence, showing the ratio between the number of accidents or occupational illnesses and the number of employees working.

\section{Juan Carlos Rubio-Romero}

School of Industrial Engineering. Universidad de Málaga. juro@uma.es

\author{
Manuscript Code: 490 \\ Date of Reception/Acceptance: 17.10.2014/01.06.2015
}

\begin{abstract}
Resumen
El sector de la construcción presenta unos altos índices de siniestralidad a nivel mundial. Como consecuencia de estas cifras tan negativas, existen numerosos estudios de prestigiosos autores acerca de cómo medir los niveles de seguridad y salud en la construcción mediante indicadores. Estos indicadores pueden clasificarse en base a las siguientes categorías: a)Accidentes registrados b) Evaluación de riesgos, c) Carga de trabajo, d) Formación en seguridad y salud, e)Percepción de la seguridad y salud y f) Gestión de la seguridad y salud. Sin embargo a pesar de la importancia de los indicadores como herramienta preventiva, no se han encontrado estudios acerca de los indicadores más adecuados para medir el grado de implementación del concepto Prevención a través del Diseño en los proyectos de construcción de obra civil. El objeto del presente trabajo es analizar los principales indicadores existentes para cuantificar los niveles de seguridad y salud en la construcción, y en base a este análisis, proponer y validar indicadores para medir la Prevención a través del Diseño en los proyectos de obra civil usando la técnica denominada staticized groups. La información que proporcionan los nuevos indicadores propuestos, resulta de gran utilidad para la mejora de los niveles de seguridad en las empresas del sector.
\end{abstract}

Palabras Claves: Seguridad y Salud Laboral, Indicador, Prevención a través del Diseño, Accidente, Construcción.

\section{State of the art}

In scientific publications numerous authors have published the results of research based on different indicators created to assess the influence of different variables related to levels of health and safety in construction. Examples can be seen in several studies. Authors as Øien et al (2011) established the theoretical basis for development of indicators used as early warnings of major accidents.

Hinze et al (2013) demonstrated the extent to which leading indicators can be utilized to distinguish the differences in project safety performances. Others as Camino (2008) and López Arquillos et al. (2012) proposed various indices such as TAR (Total number of accidents in a sub-group divided by the total number of accidents studied), so that the influence of variables related to accidents in the construction sector could be studied (e.g. the age of the employee, the size of company, the seriousness of the injury).

Studies such as that by Williamson et al. (1997) or Rodríguez Garzón et al (2013) proposed scales to measure the safety culture in the workplace, taking into account the different factors that influence the climate of safety in a company. Working along similar lines, Isla\&Diaz (1997) identified a series of scales for measuring the safety culture and attitudes to safety within an organization.

The concept of Prevention through Design (PtD) was defined by the National Institute for Safety and Health (NIOSH) as: "Identifying occupational health and safety needs at the design stage and redesigning processes to prevent or minimize hazards and risks related to the construction, manufacture, use and maintenance of facilities, materials and equipment." 
Based on this relatively new concept, there are many studies that show that a high percentage of accidents occurring in the construction industry could have been avoided or would have been less serious if more attention had been paid to safety when the project was being designed and drafted. (Haslam et al , 2003, Weinstein, Gambatese, \& Hecker, 2005, Behm, 2005, Gambatese, Behm, Rajendran, 2008, Gibb 2001, Haslam 2005).

Gangolells et al. (2010) found that some studies had shown that designers in general fall short of satisfying the obligation to consider working conditions in their designs (Behm, 2005, Fadier \& De la Garza, 2006 and Frijters \& Swuste, 2008). This fact, combined with the mistaken belief that designers have no influence over health and safety in building projects, means that in design work

Prevention through Design as a preventive tool is not taken into account. Despite the importance of Prevention through Design, there are hardly any studies establishing measurements, scales or indicators to quantify the degree to which Prevention through Design is implemented in construction projects.

\section{Methodology.}

The aim of this research is to define, propose, and validate a series of indicators to quantify the degree to which Prevention through Design is implemented in construction projects. The new indicators will be defined considering the bibliography describing existing indicators for measuring safety on building sites. The validation of new indicators will be achieved using the methodology staticized group. Cited methodology applied in construction research was described previously by Hallowell and Gambatese (2009)

\section{Results and discussion}

The indicators were first classified according to the categories shown in Table 1, based on the study by Flin (2000). Following an analysis of the indicators listed in the bibliography, a series of indicators was drawn up to measure the extent to which Prevention through Design was implemented in building projects.

The indicators were designed in line with the methodological guidelines in the Spanish UNE 66175:2003 standard "Quality management systems. Guide to the implementation of indicator systems" (AENOR, 2003). These guidelines were applied to both the design and validation of the new health and safety indicators for construction work.

\begin{tabular}{l} 
Table 1. Classification of health and safety indicators. Source: Self elaboration. \\
\hline Category \\
\hline Accidents recorded \\
\hline Risk assessment \\
\hline Work load \\
\hline Training in health and safety \\
\hline Perception of health and safety \\
\hline Health and safety management
\end{tabular}

\section{Analysis of indicators}

\section{Accidents recorded}

Studies of and research into occupational accidents that have occurred is one of the most widely used approaches to accident prevention in both the construction sector and other industries. All work-related accidents, regardless of whether the worker is injured, involve a series of factors which can be analysed. This is normally done by means of a codified classification system. The codes facilitate the compilation of data to analyse accident rates in the company or organisation and allow one to track changes in the indices and make comparisons with the official statistics published at intervals by organisations related to different areas of economic activity (Rubio et al, 2005).

\begin{tabular}{|c|c|c|c|}
\hline Authors & Purpose of indicator & Indicator & Definition of indicator \\
\hline $\begin{array}{l}\text { International Labour } \\
\text { Organization (ILO) }\end{array}$ & \multirow{4}{*}{$\begin{array}{l}\text { Descriptive analysis of } \\
\text { accidents }\end{array}$} & Frequency rate (FR) & $\begin{array}{l}\text { (No. of accidents during working hours leading to time off work } \\
\text { x } 1,000,000) / \text { (No. of workers employed x Average number of } \\
\text { hours worked annually per worker) }\end{array}$ \\
\hline $\begin{array}{l}\text { Instituto Nacional de } \\
\text { Seguridad e Higiene en } \\
\text { el Trabajo (INSHT) }\end{array}$ & & Severity rate (SR) & $\begin{array}{l}\text { (No. of days lost because of work-related accidents } \times 1,000 \text { ) / } \\
\text { (No. of workers employed x Average number of hours worked } \\
\text { annually per worker) }\end{array}$ \\
\hline $\begin{array}{l}\text { EU Statistical Office } \\
\text { EUROSTAT }\end{array}$ & & Incidence rate (IR) & $\begin{array}{l}\text { (No. of accidents during working hours leading to time off work } \\
\times 100,000) /(\text { No. of workers employed) }\end{array}$ \\
\hline $\begin{array}{l}\text { Bureau of Labor and } \\
\text { Statistics (BLS) }\end{array}$ & & $\begin{array}{l}\text { Average no. of days lost } \\
\text { (ADL) }\end{array}$ & $\begin{array}{l}\text { (No. of days lost because of work-related accidents) / (No. of } \\
\text { accidents during working hours leading to time off work) }\end{array}$ \\
\hline \multirow{2}{*}{ Cortés Díaz 2007} & \multirow{2}{*}{$\begin{array}{l}\text { Descriptive } \\
\text { accidents }\end{array}$} & $\begin{array}{l}\text { Cumulative accident } \\
\text { frequency rate }(\mathrm{CAF})\end{array}$ & $\begin{array}{l}\text { (No. of accidents in the } 11 \text { preceding months }+ \text { No. of } \\
\text { accidents in month }) \times(1,000,000) / \text { (Total no. of hours in } 11 \\
\text { preceding months }+ \text { No. of hours in month) }\end{array}$ \\
\hline & & $\begin{array}{l}\text { Cumulative accident severity } \\
\text { rate (CAS) }\end{array}$ & $\begin{array}{l}\text { (No. of days lost in the } 11 \text { preceding months }+ \text { No. of days lost } \\
\text { in month }) \times(1,000) /(\text { Total no. of hours in } 11 \text { preceding months } \\
+ \text { No. of hours in month) }\end{array}$ \\
\hline \multirow{4}{*}{$\begin{array}{l}\text { Camino et al } 2008 \\
\text { López-Arquillos et al } \\
2012\end{array}$} & \multirow{4}{*}{$\begin{array}{l}\text { Analyse the variables } \\
\text { involved in accidents } \\
\text { recorded in the building } \\
\text { industry over a period of } \\
\text { years, comparing these } \\
\text { variables with the severity of } \\
\text { accidents. }\end{array}$} & Total Accident Rate (TAR) & $\begin{array}{l}\text { Total no. of accidents in a sub-group of the population studied } \\
\text { / Total no. of accidents in the population studied }\end{array}$ \\
\hline & & Light Accident Rate (LAR) & $\begin{array}{l}\text { Total no. of light accidents in a sub-group of the population } \\
\text { studied / Total no. of light accidents in the population studied }\end{array}$ \\
\hline & & Serious Accident Rate (SAR) & $\begin{array}{l}\text { Total no. of serious accidents in a sub-group of the population } \\
\text { studied / Total no. of serious accidents in the population } \\
\text { studied }\end{array}$ \\
\hline & & Fatal Accidente Rate (FAR) & $\begin{array}{l}\text { Total no. of fatal accidents in a sub-group of the population } \\
\text { studied / Total no. of fatal accidents in the population studied }\end{array}$ \\
\hline
\end{tabular}


However, there are significant differences between countries in the format of notifications and the recording of work-related accidents, as occurs in the European Union (Jacinto and Aspinwall, 2004; Martínez, Rubio, \& Gibb 2010). The differences include the definition of a workplace, and the inclusion or exclusion of traffic accidents as work-related. Although efforts have been made to unify criteria, it should be borne in mind that comparisons between EU countries are not altogether reliable, in the light of the above differences. Similarly, Benavides et al (2003) compared fatal occupational injury surveillance systems between the European Union and the United States, and concluded that were enough differences to allow direct comparisons between both systems.

While the number of accidents recorded is an efficient indicator and can be used as a tool to improve health and safety standards, it has the disadvantage of being a reactive tool, which can only be used once the accident has occurred. Although it may help to prevent accidents in the future, it cannot predict or prevent those on which the analysis is based. Various authors (Webb et al., 1989, Pransky et al., 1999 and Sinclair and Tetrick, 2004) have also described another significant factor influencing statistics: a certain percentage of work-related accidents are not reported because it is not in the employee's economic interest, there is fear of sanctions, or the company's profits may be adversely affected. Table 2 shows the indicators used most frequently in the area of safety. They are those recommended by the 10th and 13th ILO International Conferences of Labour Statisticians and have been used by countless scientist, organisations and public (Instituto Nacional de Seguridad e Higiene en el Trabajo) and private bodies, of which a few of the most representative are shown in the table. In addition to these widely used indicators, as a result of our analysis of the bibliography, we have included other less common indicators which have been used by some scientist.

\section{Risk assessment}

Indicators in this category are especially significant as the assessment of risks is a powerful tool used extensively in workplace risk prevention. Literature dealing with this area shows that there are both simple and complex methods of assessment (Rubio et al, 2005). Table 3 shows the main indicators based on simplified methods of risk assessment accepted by such leading organisations as the British Standard Institution (BSI, 1996) and the Spanish Instituto Nacional de Seguridad e Higiene en el Trabajo (INSHT).

\begin{tabular}{|c|c|c|c|}
\hline Authors & Purpose of indicator & Indicator & Definition of indicator \\
\hline $\begin{array}{l}\text { British Standard Institution (BSI) } \\
\text { Instituto Nacional de Seguridad e } \\
\text { Higiene en el Trabajo (INSHT) } \\
\text { Halloweell and Gambatese 2009. } \\
\text { Rubio et al } 2005\end{array}$ & $\begin{array}{l}\text { Identify the degree of risk in an activity as a whole, } \\
\text { without taking worker exposure to the risk into } \\
\text { account }\end{array}$ & Unit Risk (UR) & (Frequency) x (Severity) \\
\hline Halloweell and Gambatese 2009 & $\begin{array}{l}\text { Identify the degree of risk in an activity, taking the } \\
\text { time workers are exposed to the risk into account }\end{array}$ & Cumulative Risk (CR) & $\begin{array}{l}\text { (Frequency) } \times \text { (Severity) } x \\
\text { (Exposure) }\end{array}$ \\
\hline Halloweell and Gambatese 2009 & $\begin{array}{l}\text { Identify the total level of risk for a set of activities, } \\
\text { based on the sum of individual risk assessments }\end{array}$ & Safety Risk Demand (SRD) & Summation of Cumulative Risk \\
\hline $\begin{array}{l}\text { Instituto Nacional de Seguridad e } \\
\text { Higiene en el Trabajo (INSHT) }\end{array}$ & $\begin{array}{l}\text { Determine the percentage of workers exposed to } \\
\text { a type of risk }\end{array}$ & $\begin{array}{l}\% \text { of workers exposed to } \\
\text { different types of risk }\end{array}$ & $\begin{array}{l}\text { (No. of workers exposed to a } \\
\text { type of risk } \times 100) / \text { (Total no. of } \\
\text { workers) }\end{array}$ \\
\hline
\end{tabular}

\section{Work load}

Indicators related to work load (table 4) can be broken down by the type of load they are intended to measure: physical or mental. Because of the characteristics of each individual, the opinion of the worker is indispensable for measuring the work load in both cases and forms the basis for assessment. Opinions are usually compiled via surveys, questionnaires or personal interviews.

\section{Training in health and safety}

The lack of training for construction workers is a problem that has been studied by various authors (Goldenhar et al 2001, O'Connor et al 2005, Brunette, 2005). Measurements of training in accident prevention are an effective tool for determining worker awareness of health and safety issues. Table 5 shows the main indicators for this area.

Perception of health and safety

The perception of health and safety by workers (table 6) is difficult to quantify as most studies are based on subjective opinions (Flin 2000, INSHT 2011).

\section{Health and safety management}

During our review of the state of the art in health and safety management, we identified various publications dealing with the effectiveness of health and safety programmes, using the indicators shown in Table 7. In view of the broad sense of "management", the indicators listed in this study could be understood as tools for the management of health and safety. However, in this sub-section we have only included indicators which have a direct relationship with the documentary management of health and safety programmes and which do not correspond to any of the categories mentioned previously.

\section{Indicators for Prevention through Design}

\section{Quantifying the implementation of Prevention through Design}

Once the review of the existing indicators was completed, the next step in order to achieve the aim of the research was to design and propose some new indicators in order to evaluate the performance of the PtD in construction projects.

Considering standard OHSA 18001 (BSI, 2007), and based on the guidelines in the UNE 66175:2003 standard "Quality management systems. Guide to the implementation of indicator systems" (AENOR, 2003) and following a format similar to that of the indicators listed in the preceding sub-sections, Table 8 lists the indicators proposed for measuring the degree of implementation of Prevention through 
Design in construction projects. These indicators measure fundamental aspects of the Prevention through Design concept as defined by the National Institute for Safety and Health (NIOSH).

\section{Validation of PtD indicators by experts}

When the list of proposed new indicators for PtD had been drawn up, they were assessed by a group of 8 experts in workplace risk prevention, following the methodology staticized group. Cited methodology applied in construction research was described by Hallowell and Gambatese (Hallowell and Gambatese, 2009). The staticized group method is very similar to Delphi technique. Although Delphi includes iterations and feedbacks, some studies have shown different opinions about the accuracy of the cited methods. While some studies found no substantial difference in the accuracy of the methods (Fischer, 1981; Sniezek 1990), other authors (Erffmeyer and Lane, 1984) prefer staticized groups approach because experts are not led to achieve a consensus on a value that could not be correct.

According to the guidelines of the method the selection of the experts is a very important factor in determining the quality of the research. In order to maintain the level of expertise, the members of the expert panel were selected according to a flexible point system.

After a review about the method Hallowell and Gambatese, (2009) suggested a minimum of eight panelist. All of them had at least 5 years' experience dealing with health and safety in the construction industry, university degrees in engineering or architecture, and advanced training in workplace risk prevention. Table 9 shows the average results of the assessment process.

In the opinion of the experts all the indicators proposed scored over 7 on a scale of 1 (not useful) to 10 (very useful). The degree of clarity in the definition of the indicators scored over 8 in all cases, while the degree of compatibility was greater than 9.

\begin{tabular}{|c|c|c|c|}
\hline Authors & Purpose of indicator & Indicator & Definition of indicator \\
\hline Meerding et al 2005 & $\begin{array}{l}\text { Measure injuries caused by } \\
\text { physical overload }\end{array}$ & Physical overload rate (POR) & $\begin{array}{l}\text { No. of musculoskeletal disorders caused by physical loads / } \\
\text { Total no. of workers }\end{array}$ \\
\hline $\begin{array}{l}\text { Instituto Nacional de } \\
\text { Seguridad e Higiene en }\end{array}$ & $\mathrm{M}$ & $\begin{array}{l}\text { How mentally demanding the } \\
\text { work is }\end{array}$ & $\begin{array}{l}\text { Assessment by the worker of the mental load of the work on } \\
\text { a scale of } 0 \text { to } 100\end{array}$ \\
\hline $\begin{array}{l}\text { el Trabajo (INSHT) } \\
\text { NASA TLX Method } \\
\text { (INSHT) }\end{array}$ & $\begin{array}{l}\text { workers regarding the mental } \\
\text { load of their work }\end{array}$ & Frustration level & $\begin{array}{l}\text { Assessment by the worker of the level of frustration on a scale } \\
\text { of } 0 \text { to } 100\end{array}$ \\
\hline
\end{tabular}

\begin{tabular}{|c|c|c|c|}
\hline Authors & Purpose of indicator & Indicator & Definition of indicator \\
\hline \multirow{3}{*}{$\begin{array}{l}\text { Instituto Nacional } \\
\text { de Seguridad } \\
\text { e Higiene en el } \\
\text { Trabajo (INSHT) }\end{array}$} & \multirow{3}{*}{$\begin{array}{l}\text { Descriptive analysis of } \\
\text { training }\end{array}$} & $\begin{array}{l}\% \text { of workers trained in accident } \\
\text { prevention }\end{array}$ & $\begin{array}{l}\text { (No. of workers trained in accident prevention x 100) / (Total } \\
\text { no. of workers) }\end{array}$ \\
\hline & & $\begin{array}{l}\% \text { of payroll invested in accident } \\
\text { prevention training }\end{array}$ & Money invested in accident prevention training / Total payroll \\
\hline & & $\begin{array}{l}\text { Average hours per worker dedicated to } \\
\text { accident prevention activities }\end{array}$ & $\begin{array}{l}\text { Total no. of worker-hours dedicated to accident prevention } \\
\text { activities / Total no. of workers }\end{array}$ \\
\hline
\end{tabular}

\begin{tabular}{|c|c|c|c|}
\hline Authors & Purpose of indicator & Indicator & Definition of indicator \\
\hline $\begin{array}{l}\text { Instituto Nacional } \\
\text { de Seguridad } \\
\text { e Higiene en el } \\
\text { Trabajo (INSHT) }\end{array}$ & $\begin{array}{l}\text { Determine the opinions } \\
\text { of workers about their } \\
\text { own working conditions }\end{array}$ & $\begin{array}{l}\text { Number of complaints from workers } \\
\text { about working conditions referring to } \\
\text { accident prevention }\end{array}$ & $\begin{array}{l}\text { Number of complaints from workers about working conditions } \\
\text { referring to accident prevention }\end{array}$ \\
\hline
\end{tabular}

\begin{tabular}{|c|c|c|c|}
\hline Authors & Purpose of indicator & Indicators & Definition of indicator \\
\hline Cortés Díaz 2007 & $\begin{array}{l}\text { Determine the } \\
\text { usefulness of safety } \\
\text { measures applied by the } \\
\text { company }\end{array}$ & Safety measure rate (SMR) & $\begin{array}{l}\text { (Safety measures } \times 5 \times 1,000,000) / \text { Total no. of emplo- } \\
\text { yee-hours worked }\end{array}$ \\
\hline $\begin{array}{l}\text { Hallowell and } \\
\text { Gambatese } 2009\end{array}$ & $\begin{array}{l}\text { Quantify the ability of } \\
\text { each component in the } \\
\text { safety programme to } \\
\text { reduce the level of risk }\end{array}$ & Safety Risk Mitigation (SRM) & $\begin{array}{l}\text { (Reduction in frequency ( } 1 / \text { worker hour)) } \times \text { (Reduction in } \\
\text { severity (impact)) } \times \text { (Reduction in exposure (worker hour)) }\end{array}$ \\
\hline $\begin{array}{l}\text { Instituto Nacional de } \\
\text { Seguridad e Higiene } \\
\text { en el Trabajo } \\
\text { (INSHT) }\end{array}$ & $\begin{array}{lr}\text { Evaluate } & \text { compliance } \\
\text { with legal } & \text { requirements } \\
\text { regarding } & \text { accident } \\
\text { prevention } & \end{array}$ & Administrative offences $(A O)$ & $\begin{array}{l}\text { Number of failures to comply detected by work inspectorate or } \\
\text { the relevant labour authority }\end{array}$ \\
\hline
\end{tabular}


Table 8. Proposed indicators for Prevention through Design . Source: Self elaboration.

\begin{tabular}{|c|c|c|}
\hline Purpose of indicator & Indicator & Definition of indicator \\
\hline $\begin{array}{l}\text { Quantify to what extent the project has been } \\
\text { designed taking PtD into account }\end{array}$ & $\begin{array}{l}\text { Safe construction procedure rate } \\
\text { (SCPR) }\end{array}$ & $\begin{array}{l}\text { Percentage of procedures designed taking health and safety } \\
\text { in construction into account }\end{array}$ \\
\hline $\begin{array}{l}\text { Quantify demand regarding health and safety } \\
\text { conditions as presented in the initial design } \\
\text { stages of the project }\end{array}$ & $\begin{array}{l}\text { Health and safety needs in design } \\
\text { (HSND) }\end{array}$ & No. of heath and safety needs detected in design stage \\
\hline $\begin{array}{l}\text { Quantify the number of construction processes } \\
\text { redesigned }\end{array}$ & $\begin{array}{l}\text { Construction processes redesigned } \\
\text { (CPR) }\end{array}$ & No. of construction processes redesigned \\
\hline $\begin{array}{l}\text { Quantify shortcomings regarding health and } \\
\text { safety conditions in the project attributable to } \\
\text { design }\end{array}$ & $\begin{array}{l}\text { Health and safety needs of project } \\
\text { (HSNP) }\end{array}$ & $\begin{array}{l}\text { No. of health and safety needs detected during project } \\
\text { execution which should have been dealt with at the design } \\
\text { stage. }\end{array}$ \\
\hline $\begin{array}{l}\text { Quantify measures for redesigning the project } \\
\text { aimed at improving health and safety conditions }\end{array}$ & Redesigning measures rate (RMR) & $\begin{array}{l}\text { ((No. of redesigning measures) } \times 100) /(\text { No. of health and } \\
\text { safety needs detected during design stage) }\end{array}$ \\
\hline
\end{tabular}

\begin{tabular}{|c|c|c|c|c|c|}
\hline Indicator Score (1-10) & $\begin{array}{l}\text { Usefulness of } \\
\text { indicator }\end{array}$ & Clarity of definition & $\begin{array}{l}\text { Compatibility with } \\
\text { other indicators }\end{array}$ & $\begin{array}{l}\text { Difficulty in compiling } \\
\text { information }\end{array}$ & $\begin{array}{l}\text { Reliability of } \\
\text { indicator }\end{array}$ \\
\hline $\begin{array}{l}\text { Safe construction procedure rate } \\
\text { (SCPR) }\end{array}$ & 8.63 & 9.13 & 9.50 & 4.50 & 8.13 \\
\hline $\begin{array}{l}\text { Health and safety needs in design } \\
\text { (HSND) }\end{array}$ & 8.25 & 8.50 & 9.25 & 5.38 & 7.88 \\
\hline $\begin{array}{l}\text { Construction processes } \\
\text { redesigned (CPR) }\end{array}$ & 8.50 & 8.88 & 9.38 & 4.25 & 8.25 \\
\hline $\begin{array}{l}\text { Health and safety needs of } \\
\text { project (HSNP) }\end{array}$ & 7.88 & 8.63 & 9.25 & 4.75 & 7.88 \\
\hline $\begin{array}{l}\text { Redesigning measures rate } \\
\text { (RMR) }\end{array}$ & 8.50 & 8.25 & 9.50 & 6.38 & 7.38 \\
\hline Average & 8.35 & 8.68 & 9.38 & 5.05 & 7.90 \\
\hline
\end{tabular}

\section{Conclusions}

Our review of the bibliography has allowed us to select 24 indicators which will serve as a tool for the effective measurement of occupational health and safety on building sites. In the light of this review and the importance of Prevention through Design, 5 indicators have been proposed and validated to measure the degree to which Prevention through Design is implemented. The validation of the indicators by experts in health and safety in the field of construction has given positive results.

In addition to this positive validation by the experts, the usefulness of health and safety indicators as a powerful tool for workplace risk prevention has been confirmed both scientifically, in the bibliography consulted, and at the institutional level, in the documentation to which the authors have had access from prestigious bodies such as the International Labor Organization, and the Instituto Nacional de Seguridad e Higiene en el Trabajo.

\section{Impact on the industry}

The indicators we have compiled and analysed, together with the new indicators created to quantify the inclusion of Prevention through Design in construction projects, will be very helpful for those companies in the civil engineering works sector who hope to improve occupational health and safety conditions, taking advantage of the information provided by the proper use of the indicators described in this paper.

\section{Limitations of the study}

The study is based on reviews of bibliography and the state of the art regarding health and safety indicators in the construction industry. It has not, therefore, been possible for the authors to apply the results on specific construction sites with a view to obtaining conclusions based on putting them into practice.

\section{Future lines of research}

It would be of great practical value to be able to apply the indicators proposed in this study to real cases in the construction industry to obtain practical measurements of their effectiveness in improving standards of health and safety.

\section{Acknowledgements}

This study has been funded by the Spanish Government [Ministry of Science and Technology] and the European Union [FEDER] as part of the project "seguridad desde el diseño en la ejecución de tareas de encofrado en obra civil", reference BIA2011-27338 in the National Research and Development Plan list of approved projects. 
UNE 66175:2003. Sistemas de gestión de la calidad. Guía para la implantación de sistemas de indicadores. Asociación Española de Normalización. España

Behm, M. (2005). Linking construction fatalities to the design for construction safety concept. Safety Science, 43(8), 589-611.

Benavides, F. G., Delclos, G. L., Cooper, S. P. \& Benach, J. (2003). Comparison of fatal occupational injury surveillance systems between the European Union and the United States. American journal of industrial medicine, 44(4), 385-391.

Bureau of Labor Statistics. [Online]. National census of fatal occupational injuries in 2010 (preliminary results). Retrieved from http:// www.bls.gov/news.release/archives/cfoi_08252011.pdf. [visited 30.05.2013]

BS8800. Guide to occupational Health and Safety Management Systems. British Standard Institution, London

Brunette, M. J. (2005). Development of educational and training materials on safety and health: Targeting hispanic workers in the construction industry. Family \& Community Health, 28(3), 253.

Camino Lopez, M. A., Ritzel, D. O., Fontaneda, I. \& Gonzalez Alcantara, O. J. (2008). Construction industry accidents in spain. Journal of Safety Research, 39(5), 497-507. doi: 10.1016/j.jsr.2008.07.006; 10.1016/j.jsr.2008.07.006

Cortés Díaz, J. M. (2007). Técnicas de prevención de riesgos laborales. Seguridad e higiene del trabajo (9o ed.). Madrid: Tébar.

Erffmeyer, R. C. \& Lane, I. M. (1984). Quality and acceptance of an evaluative task: The effects of four group decision-making formats. Group \& Organization Management, 9(4), 509-529.

Fadier, E. \& De la Garza, C. (2006). Safety design: Towards a new philosophy. Safety Science, 44(1), 55-73.

Fischer, G. W. (1981). When oracles fail-A comparison of four procedures for aggregating subjective probability forecasts. Organizational Behavior and Human Performance, 28(1), 96-110.

Flin, R., Mearns, K., O'Connor, P. \& Bryden, R. (2000). Measuring safety climate: Identifying the common features. Safety Science, 34(1), 177-192.

Frijters, A. C., \& Swuste, P. H. (2008). Safety assessment in design and preparation phase. Safety science, 46(2), 272-281.

Gambatese, J. A., Behm, M. \& Rajendran, S. (2008). Design's role in construction accident causality and prevention: Perspectives from an expert panel. Safety Science, 46(4), 675-691.

Gangolells, M., Casals, M., Forcada, N., Roca, X. \& Fuertes, A. (2010). Mitigating construction safety risks using prevention through design. Journal of safety research, 41(2), 107-122.

Gibb, A. G. F., Haslam, R. A. \& Gyi, D. E. (2001). Cost and benefit implications and strategy for addressing occupational health in construction. Conseil Internationale de Batiment, Working Commission W99, 29-38.

Goldenhar, L. M., Moran, S. K. \& Colligan, M. (2001). Health and safety training in a sample of open-shop construction companies. Journal of Safety Research, 32(2), 237-252.

Hallowell, M. R. \& Gambatese, J. A. (2009)a. Activity-based safety risk quantification for concrete formwork construction. Journal of Construction Engineering and Management, 135(10), 990-998
Hallowell, M. R. \& Gambatese, J. A. (2009)b. Qualitative research: Application of the Delphi method to CEM research. Journal of construction engineering and management, 136(1), 99-107.

Haslam, R., Hide, S., Gibb, A. G. F., Gyi, D. E., Pavitt, T., Atkinson, S. \& Duff, A. (2005). Contributing factors in construction accidents. Applied Ergonomics, 36(4), 401-415.

Hinze, J., Thurman, S. \& Wehle, A. (2013). Leading indicators of construction safety performance. Safety science, 51(1), 23-28.

Haslam, R. A., Hide, S. A., Gibb, A. G. F., Gyi, D. E., Atkinson, S., Pavitt, T. C. \& Suraji, A. (2003). Causal factors in construction accidents. Health and Safety Executive, 156.

International Labor Organization. [Online]. Retrieved from http:// www.ilo.org/global/statistics-and-databases/statistics-overview-and-topics/safety-and-health/lang--es/index.htm [visited 03.06.2013]

Instituto Nacional de Seguridad e Higiene en el Trabajo [Online] Retrieved from http://www.oect.es/InshtWeb/Contenidos/ Documentacion/FichasTecnicas/NTP/Ficheros/601a700/ntp_640. pdf [visited 05.06.2013]

Isla Díaz, R. \& Díaz Cabrera, D. (1997). Safety climate and attitude as evaluation measures of organizational safety. Accident Analysis \& Prevention, 29(5), 643-650.

Jacinto, C. \& Aspinwall, E. (2004). A survey on occupational accidents' reporting and registration systems in the European Union. Safety Science, 42(10), 933-960.

López-Arquillos, A., Rubio-Romero, J. \& Gibb, A. (2012). Analysis of construction accidents in Spain, 2003-2008. Journal of Safety Research, 43(5), 381-388.

Martínez Aires, M. D., Rubio Gámez, M. C. \& Gibb, A. (2010). Prevention through design: The effect of european directives on construction workplace accidents. Safety Science, 48(2), 248-258.

Meerding, W., IJzelenberg, W., Koopmanschap, M., Severens, J. \& Burdorf, A. (2005). Health problems lead to considerable productivity loss at work among workers with high physical load jobs. Journal of Clinical Epidemiology, 58(5), 517-523.

O'Connor, T., Loomis, D., Runyan, C., dal Santo, J. A. \& Schulman, M. (2005). Adequacy of health and safety training among young latino construction workers.Journal of Occupational and Environmental Medicine, 47(3), 272-277.

OHSAS 18007: Occupational Health and Safety Management System - Specification. London: British Standard Institution.

$\varnothing$ ¿ien, K., Utne, I. B. \& Herrera, I. A. (2011). Building safety indicators: Part 1-theoretical foundation. Safety science, 49(2), 148-161.

Pransky, G., Snyder, T., Dembe, A. \& Himmelstein, J. (1999). Under-reporting of work-related disorders in the workplace: A case study and review of the literature. Ergonomics, 42(1), 171-182.

Rodríguez Garzón, I., Martínez-Fiestas, M. \& López Alonso, M. (2013). El riesgo percibido por el trabajador de la construcción: ¿ qué rol juega el oficio?. Revista de la Construcción, 12(3), 83-90.

Rubio Romero, J.C \& otros. (2005). Manual para la formación de nivel superior en prevención de riesgos laborales . Madrid: Díaz de Santos.

Sinclair, R. R. \& Tetrick, L. E. (2004). Pay and benefits: The role of compensation systems in workplace safety. Washington, DC: American Psychological Association. 
Sniezek, J. A. (1990). A comparison of techniques for judgmental forecasting by groups with common information. Group \& Organization Management, 15(1), 5-19.

Webb, G., Redman, S., Wilkinson, C. \& Sanson-Fisher, R. (1989) Filtering effects in reporting work injuries*. Accident Analysis \& Prevention, 21(2), 115-123.

Weinstein, M., Gambatese, J. \& Hecker, S. (2005). Can design improve construction safety?: Assessing the impact of a collaborative safety-in-design process. Journal of Construction Engineering and Management, 131(10), 1125-1134.

Williamson, A. M., Feyer, A. M., Cairns, D. \& Biancotti, D. (1997). The development of a measure of safety climate: The role of safety perceptions and attitudes. Safety Science, 25(1), 15-27. 